\title{
Redox balance and tissue development of juvenile Piaractus mesopotamicus subjected to high stocking density and fed dry diets containing nutraceutical food
}

\author{
Débora B. Moretti ${ }^{1}$, Wiolene M. Nordi ${ }^{1}$ \& Raul Machado-Neto ${ }^{1}$ \\ ${ }^{1}$ Animal Science Department, Luiz de of Queiroz College Agriculture \\ University of São Paulo, Piracicaba, Brazil \\ Corresponding author: Débora B. Moretti (dmoretti@usp.br)
}

\begin{abstract}
Colostrum is a source of molecules with nutraceutical features that can attenuate the consequences of adverse conditions, such as densification. Thus, the redox balance and tissue development of juvenile Piaractus mesopotamicus subjected to high stocking density and fed diets containing lyophilized bovine colostrum (LBC) were evaluated. Juveniles were distributed into 16 cages making $50 \mathrm{~kg}_{\text {fish m}}^{-3}$ and fed diets containing 0,10, 20 and 30\% inclusion of LBC $(n=4)$. After 30 days, enteric, hepatic, muscular, renal and branchial tissue were sampled for the determination of glutathione peroxidase (GPx), superoxide dismutase (SOD) and catalase activity, oxygen radical absorbance capacity (ORAC), lipid peroxidation and protein and nucleotides content. SOD activity and DNA content were higher in $20 \%$ LBC compared to the others in the enteric tissue $(P<0.10)$. ORAC value in erythrocytes was higher in $30 \% \mathrm{LBC}$ than 0 and $10 \% \mathrm{LBC}(P<0.10)$. Juveniles fed $10 \%$ LBC showed higher lipid peroxidation in liver than 0 and $20 \%$ LBC $(P<0.10)$ and those fed $20 \%$ LBC showed lower protein/RNA ratio compared to the others $(P<0.10)$. Bovine colostrum determined a decrease in liver protein synthesis and increased in intestinal DNA content with an intake of $20 \%$ of this milk secretion. Additionally, LBC increased the protection of the enteric tissue of juveniles from superoxide radicals and blood antioxidant capacity. We conclude that bovine colostrum can be used as a nutraceutical food for fish, with positive effect in redox balance and tissue development in high concentrations of inclusion in the diet, 20 and $30 \%$.
\end{abstract}

Keywords: Piaractus mesopotamicus; bovine colostrum; antioxidant; redox homeostasis; DNA; RNA; Neotropical fish

\section{INTRODUCTION}

Management practices of intensive fish farming such as transport, handling, biometrics, vaccination and temperature changes are conditions that can induce stress in fish. Acutely-induced stress causes an immunosuppressive effect, leading to large losses from illness. Chronically induced stress, when animals are kept for an extended period in inappropriate situations such as incorrect $\mathrm{pH}$, low oxygenation and overpopulation, in addition to reduced resistance to pathogens, leads to decreased growth and reproductive failures (Schep et al., 1999; Urbinati \& Carneiro, 2004; Falcon et al., 2008; Baldwin, 2010; Urbinati \& Golçalves, 2010).

The release of catecholamines and corticosteroids is a mechanism involved in the physiological response to stress that affects oxygen transport, hydromineral balance and serum glycogen, besides being related to inhibition of growth, reproduction and immune response in fish (Diniz \& Honorato, 2012). Another consequence of stress is the production of reactive oxygen species (ROS), generated by the incomplete reduction of oxygen (Berra et al., 2006). Daily mitochondrial respiration, responsible for the generation of energy for the metabolic process under normal conditions, generates ROS as a byproduct. However, the increase in the metabolism under challenging conditions generates an imbalance in the production of ROS and antioxidants, which results in oxidative stress (Gutiérrez et al., 2006). The ROS superoxide anion $\left(\mathrm{O}_{2}^{-}\right)$, hydrogen peroxide $\left(\mathrm{H}_{2} \mathrm{O}_{2}\right)$, and hydroxyl radicals $(\mathrm{HO} \bullet)$ due to unpaired electrons are extremely

Corresponding editor: Alvaro Bicudo 
reactive and, besides the formation of lipid peroxidation of cell membranes, they attack DNA, RNA and proteins, also affecting enzymatic activity (Halliwell \& Gutteridge, 1990; Nita \& Grzybowski, 2016). The breakdown of cellular homeostasis may eventually lead to apoptosis or necrosis (RedzaDutordoir \& Averill-Bates, 2016).

The body has two groups of antioxidant factors to protect themselves against ROS, the enzymatic and non-enzymatic. In the first group, there are some enzymes such as catalase, glutathione peroxidase and superoxide dismutase. The glutathione peroxidase acts on peroxides in general, using glutathione as a cofactor, while superoxide dismutase catalyzes the dismutation of the superoxide radical anion $\left(\mathrm{O}_{2}\right)$ to hydrogen peroxide $\left(\mathrm{H}_{2} \mathrm{O}_{2}\right)$ and $\mathrm{O}_{2}$, and the catalase acts as a catalyst for the decomposition of $\mathrm{H}_{2} \mathrm{O}_{2}$ to $\mathrm{H}_{2} \mathrm{O}$ and $\mathrm{O}_{2}$. In the second group, vitamins $\mathrm{A}, \mathrm{C}$ and $\mathrm{E}$ are considered highly efficient non-enzymatic antioxidants due to the high capacity to sequester free radicals in the body, besides being crucial for several chemical reactions that maintain welfare and good physiological condition of the body (Vasconcelos et al., 2007).

The first mammalian lacteal secretion, colostrum, is a food rich in nutrients, among them, antioxidant factors (Boudry \& Thewis, 2009; Pandey et al., 2011). For mammals, the antioxidant properties of colostrum are as crucial as nutritional and immunological, and studies indicate that this potential against ROS may contribute to overcoming challenges, especially in the postnatal period, when the birth is associated with oxidative stress (Przybylska et al., 2007). This secretion contains several molecules with antioxidant properties, among them the antioxidant enzymes, vitamins $\mathrm{E}$ and $\mathrm{C}$, selenium and manganese, and has been considered as a nutraceutical food (Pandey et al., 2011). Lactoferrin, also present in colostrum, besides being responsible for the defense against microorganisms and viral infections, it acts as a nonenzymatic antioxidant because it binds to the iron generated during the destruction process or cellular inflammation, minimizing the synthesis of hydroxyl radicals (Vasconcelos et al., 2007). Lactoperoxidase, in turn, has the primary function of catalyzing the oxidation of specific molecules in order to generate reactive products with high antimicrobial activity at the expense of $\mathrm{H}_{2} \mathrm{O}_{2}$ to $\mathrm{H}_{2} \mathrm{O}$ decomposition (Przybylska et al., 2007). According to Seth \& Das (2011), colostrum is also a rich source of glutathione, a powerful antioxidant that is often described as "the ultimate antioxidant." Due to antioxidant and nutritional properties, Ahmadi et al. (2011), consider colostrum a great natural food supplement. In fish, Sakai et al. (1993) observed that the oral supply of bovine lactoferrin to rainbow trout (Oncorhynchus mykiss) determines higher resistance against bacterial infection by the activation of phagocytes. Kumari et al. (2003) also report that the inclusion of bovine lactoferrin in the diet of Asian catfish (Clarias batrachus) is capable of increasing non-specific immunity and disease resistance, supporting the possible use of lactoferrin as an immunostimulant for catfish nursery. Falahatkar (2014) observed that bovine lactoferrin could suppress the stress response in Siberian sturgeon, being the $400 \mathrm{mg}$ $\mathrm{kg}^{-1}$ the effective level. In Nile tilapia (Oreochromis niloticus), the inclusion of bovine lysozyme in the diet improved nonspecific immunity and resistance to diseases and decreased fish mortality after challenge with Aeromonas hydrophila (El-Ashram \& El-Boshy, 2008). These studies reveal that the biologically active molecules present in bovine colostrum can influence the health of other species, including fish.

Strategies that attenuate the condition of stress in fish, besides contributing to better performance rates, has the potential to minimize the rate of morbidity and mortality. Thus, the present work evaluated the redox balance and tissue development of juvenile Piaractus mesopotamicus, subjected to high stocking density and fed a dry diet containing biologically active molecules from lacteal mammary secretion.

\section{MATERIALS AND METHODS}

\section{Experimental diets}

Isonitrogenated and isoenergetic experimental pelleted diets, considering $32 \%$ of crude protein and 4,000 kcal $\mathrm{kg}^{-1}$, respectively, were formulated considering four levels of lyophilized bovine colostrum (LBC): 0, 10, 20 and $30 \%$ (Table 1). The bovine colostrum was obtained from Holstein cows of a commercial dairy farm. The first lacteal secretion after birth was collected, frozen at $20^{\circ} \mathrm{C}$ and lyophilized. The resulting powder was, then, analyzed for the bromotological composition (Table 2) and included in the diet. The diets were also evaluated for their antioxidant capacity by the Oxygen Radical Absorbance Capacity (ORAC) protocol according to Melo et al. (2015). The fluorescence decay was monitored for two hours at $37^{\circ} \mathrm{C}$ with a kinetic methodology using emission absorbance of $528 \mathrm{~nm}$ and excitation absorbance of $485 \mathrm{~nm}$ after incubation of samples with fluorescein solution $(487 \mathrm{nM})$ and AAPH (2.2'-Azobis(2-amidinopropane) dihydrochloride, 76 $\mathrm{mM})$ solution.

Values were compared with a calibration curve of Trolox (6-hydroxy-2.5, 7.8-tetramethylchroman-2carboxylic acid) and are expressed as $\mu \mathrm{mol}$ of equivalent Trolox in $\mathrm{mg}$ of total solid. The relationship 
Table 1. Composition of diets supplied to Piaractus mesopotamicus juvenile subjected to high stocking density. Guabi Nutrição Animal, Campinas, São Paulo (ingredient per kg). Vitamins: A, 2,500 UI; D3, 600,000 UI; E, 37,500 UI; K3, 3,750 mg; C, 50,000 mg; B1, 4,000 mg; B2, 4,000 mg; B6, 4,000 mg; B12, 4,000 mg; calcium pantothenate 12,000 mg; biotin $15 \mathrm{mg}$; acid folic 1,250 mg; niacin 22,500 mg. Mineral: Cu 2,500 mg; Zn 12,500 mg; I 375 mg; Se $87.5 \mathrm{mg}$; Co 125 mg; Mn 12,500 mg; Fe 15,000 mg; BHT 15,000 mg.

\begin{tabular}{lcccc}
\hline Ingredients $\left(\mathrm{g} \mathrm{kg}^{-1}\right)$ & $0 \% \mathrm{LBC}$ & $10 \% \mathrm{LBC}$ & $20 \% \mathrm{LBC}$ & $30 \% \mathrm{LBC}$ \\
\hline Bovine colostrum & - & 100 & 200 & 300 \\
Albumin & 202 & 183 & 120 & 58 \\
Gelatin & 150 & 95 & 79 & 60 \\
Starch & 466 & 456 & 435 & 425 \\
Soy oil & 80 & 53 & 37 & 14 \\
Dicalcium phosphate & 25 & 32 & 47 & 59 \\
Cellulose & 66 & 69 & 69 & 70 \\
Tryptophan & - & 0.4 & 1.3 & 2.2 \\
BHT & 0.2 & 0.2 & 0.2 & 0.2 \\
Premix & 10 & 10 & 10 & 10 \\
NaCl & 1 & 1 & 1 & 1 \\
\hline Chemical composition $\left(\mathrm{g} \mathrm{kg}^{-1}\right)$ & & & & \\
Dry matter & 921 & 919 & 914 & 910 \\
Crude protein & 313 & 313 & 315 & 313 \\
Crude fiber & 4 & 7 & 10 & 8 \\
Fat & 90 & 72 & 65 & 56 \\
Gross energy $\left(\mathrm{MJ} \mathrm{kg}^{-1}\right)$ & 18.2 & 17.9 & 17.4 & 16.8 \\
\hline
\end{tabular}

Table 2. Composition of lyophilized bovine colostrum supplied to Piaractus mesopotamicus juvenile subjected to high stocking density.

\begin{tabular}{lr}
\hline Chemical composition $\left(\mathrm{g} \mathrm{kg}^{-1}\right)$ & \\
\hline Dry matter & 962 \\
Crude protein & 684 \\
Fat & 112 \\
Crude fiber & 8 \\
Gross energy $\left(\mathrm{MJ} \mathrm{kg}^{-1}\right)$ & 23 \\
\hline
\end{tabular}

between antioxidant capacity and percentage of bovine colostrum inclusion in the diet is shown in Figure 1.

\section{High stocking density experimental design}

Sixteen cages of $40 \mathrm{~L}(28 \times 48 \times 30 \mathrm{~cm}$, each diet or treatment was performed in quadruplicate) were distributed into a tank with continuous water flow and aeration in a closed circulation system and controlled conditions of temperature, luminosity, $\mathrm{pH}$ and dissolved oxygen $\left(24 \pm 1^{\circ} \mathrm{C}\right.$; photoperiod of $12 \mathrm{~h}$; $\mathrm{pH} 8.4 \pm$ 0.3 ; and $57 \pm 7 \%$ of dissolved oxygen). Juveniles Piaractus mesopotamicus (Holmberg, 1887) with an initial weight of $140 \pm 9 \mathrm{~g}$, were distributed into the cages until the density of $50 \mathrm{~kg}$ fish $\mathrm{m}^{-3}$, a condition considered as stressful for this species according to Merola \& de Souza (1988). Diets containing 0, 10, 20 or $30 \%$ of LBC were supplied twice daily until satiety.
After 30 experimental days, the survival rate was $100 \%$, showing that all cages were maintained in the same stocking density all the period. Then, two fish from each cage were weighted and anesthetized with benzocaine $\left(0.05 \mathrm{~g} \mathrm{~L}^{-1}\right)$, after food restriction of $24 \mathrm{~h}$. Samples from blood and enteric, hepatic, muscle, gill and renal tissues were dissected. Blood samples were collected with disposable, sterile and heparinized polypropylene $(3 \mathrm{~mL})$ syringes, centrifuged at $3,000 \mathrm{x} g$ for $15 \mathrm{~min}$. and the resulting plasma was stored at $-80^{\circ} \mathrm{C}$. The erythrocytes pellet was homogenized (1:6) with Triton-x $\left(5 \mathrm{~g} \mathrm{~L}^{-1}\right)$ and the supernatant stored at $-80^{\circ} \mathrm{C}$. Tissue samples were immediately stored at $-80^{\circ} \mathrm{C}$. The Ethics Committee on Animal Use previously approved the procedures - CEUA of the "Luiz de Queiroz" College of Agriculture (ESALQ/USP), protocol No2015-13.

\section{Evaluation of oxidative stress}

Redox balance was evaluated in different tissues by determining the activity of antioxidant enzymes, oxygen radical absorbance capacity (ORAC) and lipid peroxidation. The activity of glutathione peroxidase was evaluated by the decay of the absorbance of samples incubated with $48 \mathrm{mM}$ buffer phosphate, $\mathrm{pH}$ 7.0, $0.38 \mathrm{mM}$ EDTA, $0.95 \mathrm{mM}$ sodium azide, $1 \mathrm{mM}$ glutathione, $0.12 \mathrm{mM}$ nicotinamide adenine dinucleotide phosphate, $3.2 \mathrm{U}$ of glutathione reductase, 0.02 


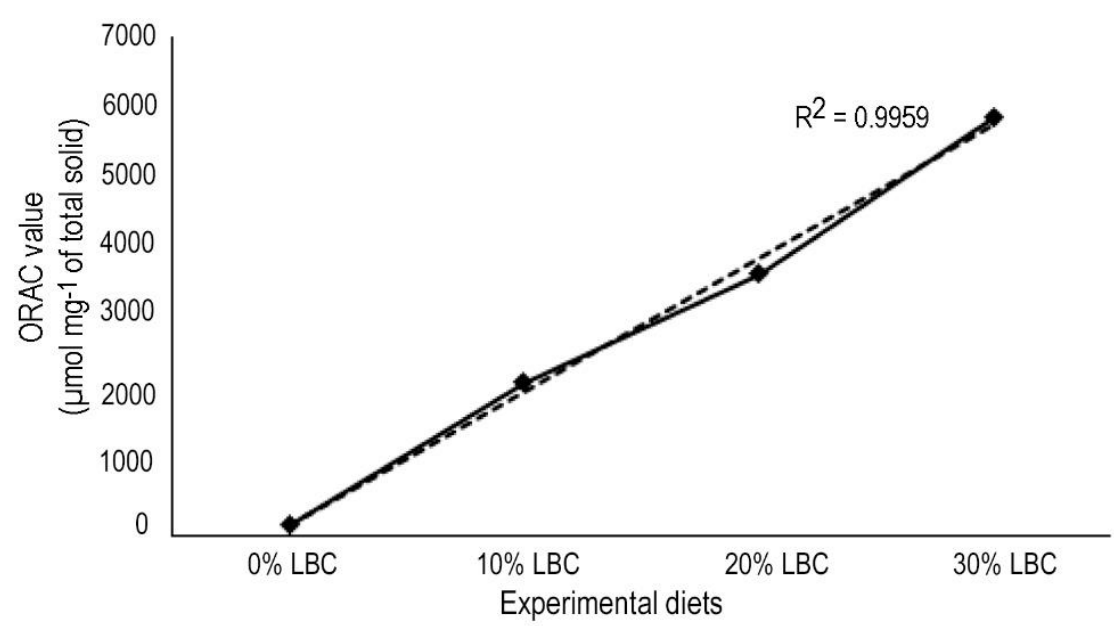

Figure 1. Relationship between antioxidant capacity and percentage of bovine colostrum inclusion in the diet supplied to pacu juvenile subjected to high stocking density. 0, 10, 20 and 30\% LBC isonitrogenated (32\% of crude protein) and isoenergetic $\left(4,000 \mathrm{kcal} \mathrm{kg}^{-1}\right)$ experimental pelleted diets formulated considering four level of lyophilized bovine colostrum (LBC) inclusion 0, 10, 20 and 30\%, respectively.

mM DL-dithiothreitol and $0.0007 \%$ hydrogen peroxide was monitored for five minutes at $340 \mathrm{~nm}$ (Wendel et al., 1981). Values are expressed as $\mathrm{U}$ per $\mathrm{mg}$ of total protein for tissues or $\mathrm{mg}$ of hemoglobin for blood, being one $U$ the amount of enzyme that catalyzes the oxidation of one $\mu \mathrm{mol}$ of reduced glutathione to oxidized glutathione per minute at $37^{\circ} \mathrm{C}, \mathrm{pH}$ 7.0. The superoxide dismutase activity was determined after incubation of samples with hypoxanthine and nitrobluetetrazolium salt and registration of color development inhibition by the samples compared against a blank (McCord \& Fridovich, 1969). The three types of SOD $(\mathrm{Cu} / \mathrm{Zn}, \mathrm{Mn}$ and FeSOD) were determined and values are expressed as unit $\mathrm{U}$ per $\mathrm{mg}$ of total protein for tissues or $\mathrm{mg}$ of hemoglobin for blood, being one $U$ the amount of enzyme needed to inhibit 50\% dismutation of the superoxide radical. Catalase activity was measured after the formation of foam resulted from the incubation of samples with triton-x (1\%) and hydrogen peroxide (30\%) in cylindrical tubes. The height of the foam was compared to a calibration curve according to Iwase et al. (2013). The values of catalase activity are expressed as $U$ per $\mathrm{mg}$ of total protein for tissues or $\mathrm{mg}$ of hemoglobin for blood, being one $\mathrm{U}$ of catalase responsible for the consumption of one $\mu \mathrm{mol}$ of $\mathrm{H}_{2} \mathrm{O}_{2}$ per minute.

Samples were also evaluated by the Oxygen Radical Absorbance Capacity (ORAC) protocol according to Melo et al. (2015), as described above. Values are expressed as $\mu$ mol of equivalent Trolox $\mathrm{mL}^{-1}$. The formation of Malondialdehyde (MDA) was determined in tissues after incubation of samples with a solution containing $15 \%$ of trichloroacetic acid and $0.375 \%$ thiobarbituric acid. The solution was boiled for $15 \mathrm{~min}$, centrifuged for $10 \mathrm{~min}$ at $3,500 \mathrm{rpm}$ and the absorbance at $532 \mathrm{~nm}$ was compared with a calibration curve of MDA. Values are expressed as nmol of MDA per $g$ of total protein for tissues or $\mathrm{g}$ of hemoglobin for blood.

\section{Evaluation of tissue development}

Tissue development was accessed by the determination of protein and nucleotide content. Tissue samples $(1 \mathrm{~g})$ were homogenized in distilled water (1:10) using ultraturrax (Polytron ${ }^{\circledR}$-Kinematica GnbH). The concentration of total protein in the homogenate was then determined by the method of Lowry et al. (1951). Quantification of DNA was determined according to the protocol established by Labarca \& Paigen (1980). DNA was extracted with perchloric acid (PCA), and content in the precipitated determined with Hoechst dye (bis-benzamide H33258, Sigma-Aldrich Co.). Calf thymus DNA (Sigma-Aldrich Co.) was used for the standard curve. The results are shown as mg of DNA g ${ }^{-1}$ of tissue. The RNA present in the supernatant from the protocol described above was determined at $260 \mathrm{~nm}$ with a spectrophotometer. The results are shown as mg RNA $\mathrm{g}^{-1}$ tissue. Relations between protein/DNA, protein/RNA and RNA/DNA were also calculated.

\section{Statistical analyses}

After confirmed for normal distribution with the Shapiro-Wilk test and homoscedasticity, data were evaluated as a randomized experimental design with four treatments and submitted to the analysis of variance, using the "General Linear Model" procedure by SAS software (SAS Institute Inc., 1999). Diffe- 
rences between means were evaluated by Duncan's test, considering alpha of 0.10 . Final weight was analyzed as co-variable $(158 \pm 27 \mathrm{~g})$ but was not significant.

\section{RESULTS}

\section{Redox balance}

No differences were observed for glutathione peroxidase and catalase values in the blood and hepatic, renal, muscle, enteric and gill tissues $(P>0.10)$ of juveniles (Table 3$)$. SOD activity was higher $(P=0.04)$ in the $20 \%$ LBC group compared to the other groups in the enteric tissue. ORAC value in erythrocytes was higher in juveniles fed $30 \% \mathrm{LBC}$ than 0 and $10 \%$ LBC $(P=$ $0.06)$. Considering $P=0.07$, TBARS value in the liver of juveniles fed $10 \%$ LBC was higher than juveniles fed 0 and $20 \%$ LBC.

\section{Tissue development}

The results for protein and nucleotide content in the enteric, hepatic, muscular, renal and gill tissues of juveniles are shown in Table 4. Effect of diet was observed for the DNA content in the enteric tissue; juveniles fed $20 \%$ LBC showed a higher value than the other groups $(P<0.10)$. Juveniles fed $20 \%$ LBC also showed lower protein/RNA ratio in the liver than juveniles fed 0\% LBC and 30\% LBC $(P<0.05)$.

\section{DISCUSSION}

The present investigation evaluated the possibility of used bovine colostrum as nutraceutical food, which attenuates the adverse effects of high stocking density in redox balance and tissue development. Colostrum is a lacteal secretion rich in molecules that have biological activity against inflammation, microbes and reactive oxygen species (Boudry \& Thewis, 2009; Pandey et al., 2011). In this work, colostrum was included in the diets in the lyophilized form to preserve the biological activity of molecules, and the pelletizing process was maintained at a temperature below protein breakdown $\left(56^{\circ} \mathrm{C}\right)$. Diet processing care resulted in a high determination index $\left(\mathrm{R}^{2}=0.99\right)$ between antioxidant capacity and inclusion of colostrum in the diet, indicating that there was a high possibility of cellular protection with the ingestion of these diets. In the mammal, in addition to coming into an environment with a much higher concentration of oxygen than the intrauterine environment after birth, the antioxidant defenses of the newborn are not entirely developed, conditions that can lead to oxidative stress (Przybylska et al., 2007). Thereby, colostrum consumption is crucial for antioxidant defense, since this first milk secretion is much higher in antioxidant capacity and radical scavenging activity than subsequent lacteal secretions (Zarban et al., 2009).

Effect of colostrum ingestion in redox balance was observed to superoxide dismutase activity in intestinal tissue. Moretti et al. (2017) also observed an increase of SOD activity in the intestine of Piaractus mesopotamicus fed with $20 \%$ of LBC inclusion in the diet. The authors suggest a positive effect of bovine colostrum intake in enteric cell protection. Kwon et al. (2010) showed that bovine colostrum also increases SOD, GPx and CAT activity of rats subjected to intestinal ischemia/reperfusion. Tang et al. (2013) evaluating the effects of dietary copper on the antioxidant defense of the intestine of young grass carp Ctenopharyngodon idella, suggest an improvement of intestinal health with the increase in the activity of antioxidant enzymes and decrease in lipid peroxidation and protein oxidation. Oxidative stress is related to an imbalance between the antioxidant defenses and the generation of free radicals (Gutiérrez et al., 2006). In the present work, lipid peroxidation was not changed while SOD activity increased in the intestine, leading us to suggest that juvenile fed $20 \%$ LBC were in a better redox balance than juveniles fed 0,10 and 30\% LBC, since these juveniles have more ability to scavenge the oxygen radicals. Pontin (2018) observed the decreased rate of apoptosis in the intestinal tissue of $P$. mesopotamicus receiving diets with a high concentration of bovine colostrum and subjected to high stocking density. The authors suggest that growth and antioxidant factors present in the diets containing colostrum may be responsible for this result. The positive relationship between ORAC value and level of colostrum inclusion in the diets corroborates this hypothesis. Although the activity of antioxidant enzymes, and TBARS values, did not change in blood, the antioxidant capacity (ORAC value) in juveniles, fed with $30 \% \mathrm{LBC}$, was higher in relation to 0 and $10 \%$ $\mathrm{LBC}$, indicating a positive influence of dietary intake with the nutraceutical feeding on the redox balance of juveniles subjected to high stock densities. Linear regression between diets and ORAC values was observed $(P<0.05)$, showing an $\mathrm{R}^{2}=0.99$.

Effect of bovine colostrum ingestion in tissue development was also observed in enteric tissue, again indicating a positive effect of the diet containing $20 \%$ of LBC. Total protein content, DNA and RNA concentrations are indicators of cellular activity of fish tissues that are under the influence of growth rate and cellular metabolism (Gwak et al., 2003; Chícharo \& Chícharo, 2008; Sivaraman et al., 2009). Nordi et al. (2017) evaluating the effect of bovine colostrum in the 
Table 3. Redox balance in different tissues of Piaractus mesopotamicus juveniles juvenile fed with $0,10,20$ and $30 \%$ of lyophilized bovine colostrum and subjected to high stocking density $\left(50 \mathrm{~kg} \mathrm{fish} \mathrm{m}^{-3}\right)$, mean \pm standard error. ${ }^{\mathrm{a}, \mathrm{b}}$ Means with different letters in the line differ by Duncan test, $P<0.10 .{ }^{1}$ Treatments: $0 \%$ LBC; $10 \%$ LBC; $20 \%$ LBC; $30 \%$ LBC - juvenile fed diets containing $0,10,20$ and $30 \%$ of lyophilized bovine colostrum, respectively; ${ }^{2}$ Values are expressed as $\mathrm{U}$ per $\mathrm{mg}$ of total protein for tissues or $\mathrm{mg}$ of hemoglobin for blood; ${ }^{4}$ Values are expressed as $\mu \mathrm{mol}$ of equivalent Trolox per $\mathrm{mg}$ of total protein for tissues or mg of hemoglobin for blood. ${ }^{5}$ Values are expressed as nmol of MDA per $\mathrm{g}$ of total protein for tissues or mmol per $\mathrm{g}$ of hemoglobin for blood.

\begin{tabular}{|c|c|c|c|c|c|}
\hline \multirow{2}{*}{ Oxidative stress parameters } & \multicolumn{4}{|c|}{ Treatments $^{1}$} & \multirow{2}{*}{$P$-value } \\
\hline & $0 \%$ LBC & $10 \% \mathrm{LBC}$ & $20 \% \mathrm{LBC}$ & $30 \%$ LBC & \\
\hline \multicolumn{6}{|l|}{ Glutathione peroxidase $^{2}$} \\
\hline Blood & $1.8 \pm 0.2$ & $1.4 \pm 0.3$ & $1.2 \pm 0.2$ & $1.2 \pm 0.4$ & 0.88 \\
\hline Intestine & $6.9 \pm 0.5$ & $7.0 \pm 0.9$ & $5.7 \pm 1.4$ & $5.0 \pm 0.2$ & 0.34 \\
\hline Liver & $0.6 \pm 0.1$ & $0.3 \pm 0.1$ & $0.4 \pm 0.1$ & $0.4 \pm 0.1$ & 0.47 \\
\hline Muscle & $6.0 \pm 0.5$ & $6.2 \pm 0.3$ & $5.3 \pm 0.3$ & $6.0 \pm 0.4$ & 0.47 \\
\hline Kidney & $4.6 \pm 1.5$ & $3.9 \pm 0.6$ & $3.0 \pm 0.8$ & $4.2 \pm 1.1$ & 0.81 \\
\hline Gills & $3.9 \pm 0.4$ & $3.2 \pm 0.2$ & $3.7 \pm 0.5$ & $3.6 \pm 0.5$ & 0.62 \\
\hline \multicolumn{6}{|l|}{ Superoxide dismutase $^{2}$} \\
\hline Blood & $5.7 \pm 0.9$ & $6.5 \pm 1.5$ & $9.2 \pm 3.6$ & $6.5 \pm 1.5$ & 0.18 \\
\hline Intestine & $417.8 \pm 74.4 b$ & $354.5 \pm 57.2 b$ & $751.9 \pm 132.0 \mathrm{a}$ & $448.1 \pm 83.6 b$ & 0.04 \\
\hline Liver & $42.3 \pm 6.7$ & $23.5 \pm 6.5$ & $27.2 \pm 4.8$ & $47.0 \pm 9.4$ & 0.23 \\
\hline Muscle & $30.3 \pm 3.7$ & $39.6 \pm 5.0$ & $36.7 \pm 3.0$ & $31.5 \pm 2.5$ & 0.28 \\
\hline Kidney & $18.3 \pm 3.8$ & $27.6 \pm 3.8$ & $23.8 \pm 1.8$ & $22.9 \pm 1.7$ & 0.22 \\
\hline Gills & $35.1 \pm 5.0$ & $26.3 \pm 3.8$ & $26.3 \pm 7.9$ & $29.1 \pm 2.8$ & 0.57 \\
\hline \multicolumn{6}{|l|}{ Catalase $^{2}$} \\
\hline Blood & $2.9 \pm 0.1$ & $3.2 \pm 0.1$ & $3.0 \pm 0.2$ & $2.9 \pm 0.1$ & 0.30 \\
\hline Intestine & $113 \pm 11$ & $104 \pm 9$ & $98 \pm 14$ & $102 \pm 11$ & 0.81 \\
\hline Liver & $7 \pm 3$ & $4 \pm 1$ & $4 \pm 1$ & $7 \pm 1$ & 0.31 \\
\hline Muscle & $25 \pm 3$ & $20 \pm 2$ & $25 \pm 4$ & $26 \pm 4$ & 0.61 \\
\hline Kidney & $10 \pm 1$ & $11 \pm 1$ & $11 \pm 1$ & $14 \pm 1$ & 0.26 \\
\hline Gills & $5 \pm 1$ & $3 \pm 1$ & $3 \pm 1$ & $3 \pm 1$ & 0.17 \\
\hline \multicolumn{6}{|l|}{ ORAC $^{3}$} \\
\hline Blood & $237 \pm 12 b$ & $216 \pm 37 b$ & $264 \pm 18 a b$ & $324 \pm 32 \mathrm{a}$ & 0.06 \\
\hline Intestine & $1,318 \pm 164$ & $1,450 \pm 166$ & $1,221 \pm 196$ & $1,268 \pm 194$ & 0.82 \\
\hline Liver & $107 \pm 11$ & $99 \pm 9$ & $103 \pm 13$ & $95 \pm 9$ & 0.87 \\
\hline Muscle & $71 \pm 5$ & $76 \pm 8$ & $86 \pm 9$ & $74 \pm 3$ & 0.42 \\
\hline Kidney & $60 \pm 5$ & $54 \pm 4$ & $55 \pm 4$ & $51 \pm 5$ & 0.55 \\
\hline Gills & $206 \pm 26$ & $231 \pm 21$ & $220 \pm 22$ & $234 \pm 24$ & 0.82 \\
\hline \multicolumn{6}{|l|}{ TBARS $^{4}$} \\
\hline Blood & $15 \pm 1$ & $14 \pm 1$ & $15 \pm 1$ & $15 \pm 1$ & 0.97 \\
\hline Intestine & $33 \pm 10$ & $55 \pm 25$ & $72 \pm 26$ & $48 \pm 26$ & 0.68 \\
\hline Liver & $10 \pm 2 b$ & $22 \pm 4 a$ & $7.7 \pm 4 b$ & $14 \pm 4 a b$ & 0.07 \\
\hline Muscle & $5.8 \pm 0.1$ & $6.4 \pm 0.3$ & $5.7 \pm 0.1$ & $6.2 \pm 0.3$ & 0.19 \\
\hline Kidney & $1,478 \pm 97$ & $1,626 \pm 97$ & $1,687 \pm 183$ & $1,706 \pm 129$ & 0.62 \\
\hline Gills & $1,057 \pm 343$ & $1,470 \pm 90$ & $1,181 \pm 353$ & $1,362 \pm 188$ & 0.70 \\
\hline
\end{tabular}

indicators of cellular activity, did not observe changes in protein, DNA and RNA content in the intestine and liver of P. mesopotamicus. Pauletti et al. (2007), in turn, reported an increase in DNA concentration in the muscle of Pseudoplatystoma fasciatum fed with the same lacteal secretion. The inclusion of $20 \%$ of LBC in the diet of juvenile P. mesopotamicus increased DNA content in intestinal tissue, indicating an increase in cell density which may be a result of an increase of cell proliferation or decrease, in agreement with the observations made by Pontin (2018), in apoptosis rate. Juveniles fed $20 \%$ LBC also showed a lower liver protein/RNA ratio than the other groups. This variable indicates an endogenous synthesis of protein resulted from translation, suggesting that colostrum decreased the liver production of proteins.

The nutraceutical proprieties of bovine colostrum have been investigated in different species (King et al., 
Table 4. Tissue development of Piaractus mesopotamicus juveniles fed with $0,10,20$ and $30 \%$ of lyophilized bovine colostrum and subjected to high stocking density $\left(50 \mathrm{~kg}\right.$ fish $\left.\mathrm{m}^{-3}\right)$, mean \pm standard error. ${ }^{{ }^{\mathrm{a}, \mathrm{b}} \mathrm{b}}$ Means with different letters in the line differ by Duncan test, $P<0.10 .{ }^{1}$ Treatments: 0\% LBC; $10 \%$ LBC; $20 \%$ LBC; 30\% LBC-juvenile fed diets containing $0,10,20$ and $30 \%$ of lyophilized bovine colostrum, respectively.

\begin{tabular}{|c|c|c|c|c|c|}
\hline \multirow{2}{*}{ Parameters } & \multicolumn{4}{|c|}{ Treatments $^{1}$} & \multirow{2}{*}{$P$-value } \\
\hline & $0 \% \mathrm{LBC}$ & $10 \% \mathrm{LBC}$ & $20 \% \mathrm{LBC}$ & $30 \% \mathrm{LBC}$ & \\
\hline \multicolumn{6}{|c|}{ DNA, mg g of tissue ${ }^{-1}$} \\
\hline Intestine & $0.8 \pm 0.1 b$ & $0.6 \pm 0.1 b$ & $1.3 \pm 0.2 \mathrm{a}$ & $0.7 \pm 0.2 b$ & 0.04 \\
\hline Liver & $0.6 \pm 0.2$ & $0.6 \pm 0.2$ & $0.6 \pm 0.1$ & $0.7 \pm 0.1$ & 0.96 \\
\hline Muscle & $0.6 \pm 0.1$ & $0.6 \pm 0.1$ & $0.6 \pm 0.1$ & $0.6 \pm 0.1$ & 0.80 \\
\hline Kidney & $5.2 \pm 0.3$ & $4.4 \pm 0.5$ & $5.7 \pm 0.3$ & $5.1 \pm 0.5$ & 0.25 \\
\hline Gills & $0.20 \pm 0.03$ & $0.23 \pm 0.02$ & $0.21 \pm 0.03$ & $0.23 \pm 0.02$ & 0.67 \\
\hline \multicolumn{6}{|c|}{ RNA, mg g of tissue ${ }^{-1}$} \\
\hline Intestine & $5.9 \pm 2.0$ & $3.4 \pm 1.3$ & $6.6 \pm 1.5$ & $6.3 \pm 1.5$ & 0.51 \\
\hline Liver & $13 \pm 1$ & $14 \pm 2$ & $17 \pm 2$ & $13 \pm 1$ & 0.38 \\
\hline Muscle & $3.1 \pm 0.4$ & $3.9 \pm 0.3$ & $3.4 \pm 0.6$ & $2.8 \pm 0.6$ & 0.51 \\
\hline Kidney & $37 \pm 6$ & $34 \pm 3$ & $42 \pm 2$ & $36 \pm 7$ & 0.67 \\
\hline Gills & $30 \pm 2$ & $32 \pm 1$ & $27 \pm 2$ & $30 \pm 3$ & 0.49 \\
\hline \multicolumn{6}{|c|}{ Protein, mg g of tissue ${ }^{-1}$} \\
\hline Intestine & $160 \pm 11$ & $152 \pm 11$ & $157 \pm 3$ & $179 \pm 5$ & 0.18 \\
\hline Liver & $249 \pm 15$ & $285 \pm 26$ & $248 \pm 25$ & $251 \pm 4$ & 0.49 \\
\hline Muscle & $149 \pm 6$ & $157 \pm 13$ & $163 \pm 7$ & $153 \pm 10$ & 0.74 \\
\hline Kidney & $200 \pm 13$ & $217 \pm 5$ & $208 \pm 26$ & $209 \pm 13$ & 0.89 \\
\hline Gills & $220 \pm 13$ & $213 \pm 2$ & $208 \pm 15$ & $218 \pm 6$ & 0.85 \\
\hline \multicolumn{6}{|c|}{ Protein/DNA } \\
\hline Intestine & $245 \pm 64$ & $286 \pm 37$ & $165 \pm 48$ & $293 \pm 70$ & 0.21 \\
\hline Liver & $577 \pm 171$ & $806 \pm 244$ & $386 \pm 56$ & $432 \pm 117$ & 0.40 \\
\hline Muscle & $248 \pm 8$ & $265 \pm 19$ & $272 \pm 18$ & $242 \pm 15$ & 0.51 \\
\hline Kidney & $39 \pm 4$ & $44 \pm 6$ & $37 \pm 6$ & $41 \pm 4$ & 0.79 \\
\hline Gills & $1,220 \pm 284$ & $958 \pm 100$ & $1,061 \pm 98$ & $953 \pm 96$ & 0.58 \\
\hline \multicolumn{6}{|c|}{ Protein/RNA } \\
\hline Intestine & $121 \pm 52$ & $117 \pm 58$ & $31 \pm 6$ & $41 \pm 11$ & 0.27 \\
\hline Liver & $19 \pm 1 a$ & $23 \pm 4 a$ & $12 \pm 1 b$ & $20 \pm 1 \mathrm{a}$ & 0.01 \\
\hline Muscle & $56 \pm 12$ & $41 \pm 6$ & $60 \pm 21$ & $80 \pm 31$ & 0.64 \\
\hline Kidney & $5.7 \pm 0.8$ & $6.6 \pm 0.6$ & $5.0 \pm 0.8$ & $6.3 \pm 1.1$ & 0.56 \\
\hline Gills & $7.3 \pm 0.7$ & $6.7 \pm 0.2$ & $7.7 \pm 0.3$ & $7.4 \pm 0.8$ & 0.68 \\
\hline \multicolumn{6}{|l|}{ RNA/DNA } \\
\hline Intestine & $11 \pm 5$ & $7 \pm 4$ & $7 \pm 3$ & $8 \pm 2$ & 0.88 \\
\hline Liver & $32 \pm 10$ & $31 \pm 9$ & $48 \pm 20$ & $22 \pm 5$ & 0.60 \\
\hline Muscle & $5.1 \pm 0.7$ & $6.7 \pm 0.6$ & $5.6 \pm 1.1$ & $4.3 \pm 1.1$ & 0.35 \\
\hline Kidney & $7.3 \pm 1.3$ & $7.6 \pm 1.3$ & $7.4 \pm 0.2$ & $7.1 \pm 1.4$ & 0.99 \\
\hline Gills & $167 \pm 22$ & $146 \pm 18$ & $139 \pm 13$ & $135 \pm 17$ & 0.61 \\
\hline
\end{tabular}

2005; Huguet et al., 2006; Lima et al., 2009; Rodrigues et al., 2010; Bodammer et al., 2011). In fish, the ingestion of this lacteal secretion leads to changes in the intestinal distribution of goblet cells (Cruz et al., 2017); intestinal activity of alkaline phosphatase (Moretti et al., 2014) and superoxide dismutase (Moretti et al., 2017); intestinal morphometric features (Rodrigues et $a l ., 2010)$; decrease in intestinal apoptosis rate (Pontin, 2018) an increase in muscle DNA content (Pauletti et al., 2007). Beyond that, specific compounds of colostrum also demonstrate a positive effect on the immune system and growth. Bovine lactoferrin, for example, determines higher resistance against bacterial infection in the rainbow trout Oncorhynchus mykiss (Sakai et al., 1993) and increases non-specific immunity and disease resistance in Asian catfish Clarias batrachus (Kumari et al., 2003). Falahatkar (2014), in turn, investigating the effect of bovine lactoferrin against stress, observed decreasing levels of cortisol and lactate in juvenile Siberian sturgeon fed bovine lactoferrin and subjected to two minutes of air exposure. The authors suggest that bovine lactoferrin may be suitable to suppress the cortisol response to stress and improve the physiological condition of $S$. 
sturgeon, being the $400 \mathrm{mg} \mathrm{kg}^{-1}$ the effective level. Bovine lysozyme also promoted the improvement of nonspecific immunity and resistance to disease in Nile tilapia (Oreochromis niloticus) challenged with Aeromonas hydrophila (El-Ashram \& El-Boshy, 2008). These results with those presented in the present study indicate the potential that the biologically active molecules present in bovine colostrum have to interfere with animal health and welfare.

\section{CONCLUSIONS}

Considering the present results, we conclude that the effect of colostrum ingestion in juvenile development is limited to enteric and hepatic tissue, determining the decrease in liver protein synthesis and increase in intestinal DNA content with the intermediate (20\%) intake of this milk secretion. Additionally, the inclusion of bovine colostrum in the diet of juvenile $P$. mesopotamicus had the potential to protect the enteric tissue from superoxide radicals, acting locally and possibly against the intracellular actions of this oxygenated radical. Bovine colostrum also increased the antioxidant protection in the blood of juveniles stored at high density. Taken all together, we conclude that bovine colostrum can be used as a nutraceutical food for P. mesopotamicus, with positive effect in redox balance and tissue development in high concentrations of inclusion in the diet, 20 and $30 \%$.

\section{ACKNOWLEDGMENTS}

Authors are indebted to Fundação de Amparo à Pesquisa do Estado de São Paulo (FAPESP, process 2014/14937-7) for the funding and support to the research project.

\section{REFERENCES}

Ahmadi, M., Velciov, A.B., Scurtu, M., Ahmadi, T. \& Olariu, L. 2011. Benefits of bovine colostrum in nutraceutical products. Journal of Agroalimentary Processes and Technologies, 17: 42-45.

Baldwin, L. 2010. The effects of stocking density on fish welfare. The Plymouth Student Scientist, 4(1): 372383.

Berra, C.M., Menck, C.F.M. \& Di Mascio, P. 2006. Oxidative stress, genome lesions and signaling pathways in cell cycle control. Química Nova, 29: 1340-1344.

Bodammer, P., Maletzki, C., Waitz, G. \& Emmrich, J. 2011. Prophylatic application of bovine colostrum amelio-rates murine colitis via induction of immu- noregulatory cells. Journal of Nutrition, 141: 10561061.

Boudry, C. \& Thewis, A. 2009. Bovine colostrum as a natural growth factor for newly-weaned piglets. Bulletin UASVM Animal Science and Biotechnologies, 66: 1-2.

Chícharo, M.A. \& Chícharo, L. 2008. RNA:DNA ratio and other nucleic acid derived indices in marine ecology. International Journal of Molecular Sciences, 9: 1453-1471.

Cruz, T.M.P., Moretti, D.B., Nordi, W.M., Cyrino, J.E.P. \& Machado-Neto, R. 2017. Dietary lyophilized c 371 colostrum alters the distribution of goblet cells and the intestinal epithelium of Piaractus mesopotamicus. Aquaculture, 468: 286-292. doi: 10.1016/j.aquaculture.2016.10.032

Diniz, N.M. \& Honorato, C.A. 2012. Stress in fish production - alternatives to lessen its effects. Arquivos de Ciências Veterinárias e Zoologia da UNIPAR, 15: 149-154.

El-Ashram, A.M.M., \& El-Boshy, M.E. 2008. Assessment of dietary bovine lactoferrin in the enhancement of immune function and disease resistance in Nile tilapia (Oreochromis niloticus). The Eighth International Symposium on Tilapia in Aquaculture, 2: 1097-1107.

Falahatkar, B. 2014. Suppression of stress responses in Siberian sturgeon, Acipenser baeri, juveniles by the dietary administration of bovine lactoferrin. Journal of the World Aquaculture Society, 45: 699-708. doi: 10.1111/jwas.12153.

Falcon, D.R., Barros, M.M., Pezzato, L.E., Solarte, W.V.N. \& Guimarães, I.G. 2008. Differential leukocyte counts of Nile tilapia fed diets supplemented vitamin $\mathrm{c}$ and lipid and submitted to low-temperature stress. Ciência Animal Brasileira, 9: 543-551.

Gutiérrez, J., Ballinger, S.W., Darley-Usmar, V.M. \& Landar, A. 2006. Free radicals, mitochondria, and oxidized lipids: the emerging role in signal transduction in vascular cells. Circulation Research, 99: 924-932.

Gwak, W.S., Tsusaki, T. \& Tanaka, M. 2003. Nutritional condition, as evaluated by RNA/DNA ratios, of hatchery-reared Japanese flounder from hatch to release. Aquaculture, 219: 503-514.

Halliwell, B. \& Gutteridge, J. 1990. Role of free radicals and catalytic metal ions in human disease: an overview. Methods in Enzymology, 186: 1-85.

Huguet, A., Sève, B., Le Dividich, J. \& Hu€erou-Luron, I.L. 2006. Effects of a bovine colostrum-supplemented diet on some gut parameters in weaned piglets. Reproduction Nutrition Development, 46: 167-178.

Iwase, T., Tajima, A., Sugimoto, S., Okuda, K., Hironaka, I., Kamata, Y., Takada, K. \& Mizunoe, Y. 2013. A 
simple assay for measuring catalase activity: a visual approach. Scientific Reports, 3: 3081-3084.

King, M.R., Ravindran, V., Morel, P.C.H., Thomas, D.V., Birtles, M.J. \& Pluske, J.R. 2005. Effects of spraydried colostrum and plasmas on the performance and gut morphology of broiler chickens. Australian Journal of Agricultural Research, 56: 811-817. doi: 10.1071/ AR04324.

Kumari, J., Swain, T. \& Sahoo, P.K. 2003. Dietary bovine lactoferrin induces changes in immunity level and disease resistance in Asian catfish Clarias batrachus. Veterinary Immunology and Immunopathology, 94: 19.

Kwon, O.Y., Lee, J.S., Choi, H.S., Hong, H.P., Jang, K.H., Paek, J.H., Kang, S.A. \& Ko, Y.G. 2010. Antioxidant and anticytokine effects of bovine colostrum in intestinal ischemia/reperfusion injured rat model. Food Science and Biotechnology, 19: 12951301.

Labarca, C. \& Paigen, K. 1980. A simple, rapid, and sensitive DNA assay procedure. Analytical Biochemistry, 102: 344-352.

Lima, A.L., Pauletti, P., Susin, I. \& Machado-Neto, R. 2009. Fluctuation of serum variables in goats and comparative study of antibody absorption in newborn kids using cattle and goat colostrum. Brazilian Journal of Veterinary Research and Animal Science, 38: 22112217.

Lowry, O.H., Rosebrough, N.J., Farr, A.L. \& Randall, R.J. 1951. Protein measurement with the Folin phenol reagent. Journal of Biological Chemistry, 193: 265275.

McCord, J.M. \& Fridovich, I. 1969. Superoxide dismutase: an enzymic function for erythrocuprein (hemocuprein). Journal of Biological Chemistry, 244: 6049-6055.

Melo, P.S., Massarioli, A.P., Denny, C., dos Santos, L.F., Franchin, M. \& Pereira, G.E. 2015. Winery byproducts: extraction optimization, phenolic composition, and cytotoxic evaluation to act as a new source of scavenging of reactive oxygen species. Food Chemistry, 181: 160-169.

Merola, N. \& de Souza, J.H. 1988. Preliminary studies on the culture of pacu, Colossoma mitrei, in floating cages: effect of stocking density and feeding rate on growth performance. Aquaculture, 68: 243-248. doi: 10.1016/0044-8486(88)90356-0.

Moretti, D.B., Nordi, W.M., Cruz, T.M.P. \& MachadoNeto, R. 2017. Catalase, superoxide dismutase, glutathione peroxidase, and oxygen radical absorbance capacity in the gut of juvenile pacu Piaractus mesopotamicus and dourado Salminus brasiliensis fed bovine first milk secretion. Latin American Journal of Aquatic Research, 45: 717-723. doi: 10.3856/vol45issue4-fulltext-8.
Moretti, D.B., Nordi, W.M., Cruz, T.M.P., Cyrino, J.E.P. \& Machado-Neto, R. 2014. Histochemical distribution of intestinal enzymes of juvenile pacu (Piaractus mesopotamicus) fed lyophilized bovine colostrum. Fish Physiology and Biochemistry, 40: 1487-1493.

Nita, M. \& Grzybowski, A. 2016. The role of the reactive oxygen species and oxidative stress in the pathomechanism of the age-related ocular diseases and other pathologies of the anterior and posterior eye segments in adults. Oxidative Medicine and Cellular Longevity: 3164734.

Nordi, W.M., Moretti, D.B., Cruz, T.M.P., Cyrino, J.E.P. \& Machado-Neto, R. 2017. Cellular activity and development of enteric, hepatic and muscle tissues of juvenile pacu Piaractus mesopotamicus (Holmberg, 1887) fed with lyophilized bovine colostrum. Aquaculture Research, 48: 1099-1109. doi:10.1111/ are.12952.

Pandey, N.N., Dar, A.A. \& Mondal, D.B. 2011. Bovine colostrum: a veterinary nutraceutical. Journal of Veterinary Medicine and Animal Health, 3: 31-35.

Pauletti, P., Kindlein, L., Bagaldo, A.R., Rodrigues, A.P.O., Delgado, E.F., Cyrino, J.E.P. \& MachadoNeto, R. 2007. Feeding juveniles of Pseudoplatystoma fasciatum (Teleostei, Pimelodidae) with lyophilized bovine colostrum: growth and protein, RNA and DNA content in liver and intestine. Journal of Animal Science, Abstracts, 85: 89.

Pontin, M.C.F. 2018. Antioxidant protection of bovine colostrum in intestinal cells of pacu juveniles (Piaractus mesopotamicus) subjected to high socking densities. Master Thesis, Luiz de Queiroz College of Agriculture, University of São Paulo, 66 pp.

Przybylska, J., Albera, E. \& Kankofer, M. 2007. Antioxidants in bovine colostrum. Reproduction in Domestic Animals, 42: 402-409.

Redza-Dutordoir, M. \& Averill-Bates, D.A. 2016. Activation of apoptosis signaling pathways by reactive oxygen species. Biochimica et Biophysica Acta Molecular Cell Research, 1863: 2977-2992.

Rodrigues, A.P.O., Pauletti, P., Kindlein, L., Delgado, E.F., Cyrino, J.E.P. \& Machado-Neto, R. 2010. Intestinal histomorphology in Pseudoplatystoma fasciatum fed bovine colostrum as a source of protein and bioactive peptides. Scientia Agricola, 67: 524-530.

Sakai, M, Otubo, T., Atsuta, S. \& Kobayashi, M. 1993. Enhancement of resistance to bacterial infection in rainbow trout, Oncorhynchus mykiss (Walbaum), by oral administration of bovine lactoferrin. Journal of Fish Diseases, 16: 239-247. doi: 10.1111/j.13652761.1993.tb01253.x.

Schep, L.J., Tucker, I.G., Young, G., Ledger, R. \& Butt, A.G. 1999. Controlled release opportunities for oral 
peptide delivery in aquaculture. Journal of Controlled Release, 59: 1-14. doi: 10.1016/S0168-3659(98) 00175-8.

Seth, R. \& Das, A. 2011. Colostrum powder and its health benefits. Compendium of lectures, winter school on chemical analysis of value added dairy products and their quality assurance. Dairy Chemistry Division National, Dairy Research Institute, Deemed University, Karnal, pp. 59-67.

Sivaraman, G.K., Kapila, R. \& Mahanta, P.C. 2009. RNADNA Ratios as an indicator of fish growth in Golden Mahseer (Tor Putitora). Asian Fisheries Science, 22: 117-123.

Tang, Q.Q., Feng, L., Jiang, W.D., Liu, Y., Jiang, J., Li, S.H., Kuang, S.Y., Tang, L. \& Zhou, X.Q. 2013. Effects of dietary copper on growth, digestive, and brush border enzyme activities and antioxidant defense of hepatopancreas and intestine for young grass carp (Ctenopharyngodon idella). Biological Trace Element Research, 155: 370-380.

Received: 17 August 2018; Accepted: 28 December 2018
Urbinati, E.C. \& Carneiro, P.C.F. 2004. Práticas de manejo e estresse dos peixes em piscicultura. In: Cyrino, J.E.P., Urbinati, E.C., Fracalossi, D.M. \& Castagnolli, N. (Eds.). Tópicos especiais em piscicultura de água doce tropical intensiva. TecArt, São Paulo, pp. 171-193.

Urbinati, E.C. \& Gonçalves, F.D. 2010. Pacu (Piaractus mesopotamicus). In: Baldisserotto, B. \& Gomes, L.C. (Eds.). Espécies nativas para a piscicultura no Brasil. UFSM, Rio Grande do Sul, pp. 205-244.

Vasconcelos, S.M.L., Goulart, M.O.F., Moura, J.B.F., Benfato, V.M.M.S. \& Kubota, L.T. 2007. Reactive oxygen and nitrogen species, antioxidants and markers of oxidative damage in human blood: main analytical methods for their determination. Química Nova, 30: 1323-1338.

Wendel, A. 1981. Glutathione peroxidase. Methods in Enzymology, 77: 325-333.

Zarban, A., Taheri, F., Chahkandi, T., Sharifzadeh, G. \& Khorashadizadeh, M. 2009. Antioxidant and radical scavenging activity of human colostrum, transitional and mature milk. Journal of Clinical Biochemistry and Nutrition, 45: 150-154. 